\title{
A Long and Winding Road: Cross-Cultural Connections Between Brazil, Australia and Japan
}

\author{
Cristina Rocha \\ University of Western Sydney
}

\section{Introduction}

My first experiences of Japan were so early in life that they are hazy in my memory. My neighbours in São Paulo City, a sprawling megalopolis in Brazil, were Japanese migrants. I was seven or eight when I first saw their festivals and performance presentations from my parents' bedroom window. I remember my awe at their colourful costumes, masks and music. On a daily basis I remember the pungent smell of the soy sauce they produced in a factory in their backyard. We also shopped at a small neighbourhood supermarket called Shinohara. We bought paper and sticks for our kites from a general store owned by another Japanese migrant. We would tell our mother that we were going to ride our bikes to the 'Japonesa' to get kite material. At home, caqui (Japanese kaki) was my favourite fruit, but we also had all sorts of vegetables the Japanese migrants brought from Japan. We even called Japanese pumpkin by its Japanese name - kabocha.

In the mid-1980s I moved to an inner city flat in São Paulo City, and perhaps those early powerful memories surfaced when I went to Japan Town (a suburb called Liberdade) looking for ikebana (flower arrangement) classes. Living in a flat made me miss the garden so much that I decided I should have my own mini-garden at home. I found classes at a Sōtō Zenshū temple, and had a wonderful time being the only gaijin amongst a dozen obachan. Just being at the temple was like stepping into a different world: the smell of incense, the altar with flowers and offerings, the constant comings and goings of the Japanese migrants. During fundraising events for the temple, I would volunteer in the kitchen with my classmates. But the most striking aspect was the learning process itself. On the first day, I asked my ikebana sensei for books so that I could learn faster. At the time, I was studying for my Bachelor of Social Sciences, and reading was the way I had always acquired knowledge. To my dismay, Sensei told me: 'no books; watch, copy and learn'. She told me flowers and branches had a 'front' and a 'back', that there should never be an even number of them in the vase, that we had to choose them according to the seasons. What did this all mean? For the first months, I was unable to see what my sensei was trying to show me. I agonised to copy the arrangements with no book to help me. That was my first inkling into a Japanese way of learning and teaching.

From then onwards, my fascination with Japanese culture just increased - I went on to study shodō (calligraphy), then nihongo (Japanese language), and finally found chadō/chanoyu (tea ceremony). In 1991, I started MPhil research on chanoyu and the 
Japanese identity, and was awarded an Urasenke scholarship to study it full-time in Kyoto for one year. In 1999 I moved to Australia, and started my PhD on Zen Buddhism in Brazil in the following year. Because I was brought up in Brazil, from early life I was surrounded by Japanese names, tastes, smells and sights. Had I lived in Australia all my life that would not have happened, although Australia is geographically much closer to Japan. The White Australia Policy - which hampered the possibility of a large migration of Japanese to the country when Japan sent migrants to the US, Peru and Brazil - coupled with the actual warfare between both countries during the Second World War has meant that Japanese culture is not as ubiquitous in Australia. In fact, one of the things I missed most once I moved to Australia was having a 'Japan Town' close by, so that I could be surrounded by the sounds and smells of Japan whenever I was missing them too much.

\section{Flows and Counterflows: the Japanese in Brazil, Brazilians in Japan}

Indeed, being surrounded by Japanese culture is part of life for most Brazilians living in the south-eastern states. Presently, there are 1.5 million Japanese and their descendants in Brazil, making it the largest Japanese community outside Japan. They are concentrated mainly in the states of São Paulo and Paraná, in the south of Brazil. The first Japanese migrants arrived in 1908 at the port of Santos, in São Paulo State. At the end of the nineteenth century, Japan was leaving a feudal system behind and embracing modernisation through rapid urbanisation and industrialisation. The consequent drastic social changes and economic difficulties hit the rural population especially hard. High inflation, combined with low rice prices and a new and rigorous land tax system, resulted in widespread poverty in rural areas. Consequently, the Meiji Government (1868-1912) saw emigration as a safety valve to relieve pressure on the land, while creating colonies that would grow food for export back to Japan. While Japan needed to find new recipients for her rural workers, Brazil was in dire need of plantation workers because of the boom in coffee production (1850s-1930) in the west of São Paulo State. This demand for a work force was made even more acute because it took place at a time when slavery was being phased out (it was finally abolished in 1888). Brazil was not the only country sought out by the Japanese Government as intense anti-Japanese sentiment built up in the US. Peru received the first group of contract labourers before Brazil, in 1899, but the high level of anti-Japanese sentiment there and the consequent violence associated with death by disease prompted officials to seek other ports. ${ }^{1}$

In light of this situation, the Meiji Government promoted Japanese immigrants as hard working, diligent, adaptable, and eager to assimilate. ${ }^{2}$ During World War II, however, like for other Allied Powers, there was an intense fear of the 'yellow peril' in Brazil, and a strong concern that the immigrants were still subjects of the

\footnotetext{
${ }^{1}$ For more on the Japanese immigration to Peru and the current state of Japanese descendants there, see Takenaka, 'Japanese Peruvians and their Ethnic Encounters', pp. 113-118.

${ }^{2}$ Lesser, Negotiating National Identity, p. 82; Lone, Japanese Community in Brazil, pp. 29, 39.
} 
Emperor. Indeed, although the Japanese were not interned in camps as they were in the US, Japanese schools were closed, Japanese language newspapers were prohibited (there were four Japanese daily newspapers published in São Paulo with a total circulation of around fifty thousand), and speaking Japanese in public and private (including houses of worship) was banned.

Nevertheless, the positive images produced in the first half of the twentieth century - of Japanese people as hard working, diligent, honest, and intelligent - have endured in Brazilian society. It is noteworthy that in the 1980s and 1990s Japan was constantly portrayed in the Brazilian media in the same way it had been at the beginning of the century: the country that became modern, and hence 'western', overnight. ${ }^{3}$ Documentaries, TV commercials, movies, magazine reports and advertisements all saturated Brazil with positive images of Japan and the corollary connection between Japan and the Japanese-Brazilians. ${ }^{4}$ Being brought up in such an environment, I was astonished to learn that the same was not true of Australia. Upon arriving here, I realised that, for the older generation, the pain of World War II - when Australians feared a Japanese invasion, and the ill-treatment in prisoners' camps was made known - meant that the Japanese were not admired as in Brazil, but still resented by some. I also realised that younger Australians, who had no memory of the war, were eager to learn Japanese and travel to Japan for tourism or on student exchanges. The same was true of the Japanese in Australia. It was interesting to see the ways in which Australia managed to attract large numbers of tourists and students by presenting itself as a place of open expanses, beautiful beaches and exotic fauna.

In Brazil, from the mid-1980s a new phenomenon intensified the flows of information, commodities, and images of Japanese culture in the southern Brazilian cities: the Brazilian-Japanese dekasegi ${ }^{5}$. Comprising a community of 268 thousand people in 2003, Brazilian workers make up the third largest migrant population in Japan, behind only Koreans (635 thousand) and Chinese (335 thousand). ${ }^{6}$ These numbers are more significant when we take into account that 18 percent of the 1.5 million Japanese-Brazilian population living in Brazil emigrated to Japan. Since the mid-1980s they have worked in jobs that are avoided by the Japanese as they are considered kiken (dangerous), kitanai (dirty) and kitsui (hard). Later on, Japanese-Brazilian workers themselves added two more Ks to the above three, describing their jobs as kibishii (strict) and kirai (loathsome).

Emigration to Japan is part of a global diaspora of Brazilians which was triggered by the country's economic crisis of the 1980s-1990s. The first wave of Brazilian dekasegi

\footnotetext{
${ }^{3}$ Ibid.

${ }^{4}$ For more on the favourable perceptions of Japanese culture and the Japanese in Brazil, see Tsuda, 'From Ethnic Affinity to Alienation', pp. 53-91. For current accounts of the globalisation and localisation of Japanese culture in the world, see Befu, 'Globalization Theory from the Bottom Up', pp. 3-22; and Iwabuchi, Recentering Globalization.

${ }^{5}$ The term dekasegi literally means 'working away from home'. It used to refer to rural workers migrating to the cities in search of work in the late $19^{\text {th }}$ century and early $20^{\text {th }}$ century. Nowadays, it is used to refer to those who go to Japan to work in order to escape economic turmoil in their original countries.

${ }^{6}$ Source: Statistics on Foreign Residents, Immigration Bureau, Ministry of Justice of Japan.
} 
arrived in Japan in the mid-1980s, and was composed of postwar issei (first-generation Japanese) and nisei (second-generation Japanese-Brazilians) who spoke fluent Japanese and retained Japanese citizenship. However, when Brazil's economic crisis worsened in the late 1980s and early 1990s, stable middle-class nisei and sansei (third-generation Japanese-Brazilians), who spoke only Portuguese and had little first-hand experience with Japanese culture, started leaving for Japan as well. By the mid-1990s, families with small children migrated on a more permanent basis. In response to the increasing numbers of Brazilians, new businesses were established in Japan to cater to this population. This included restaurants, clothing and grocery shops, newspapers, satellite TV, video rental shops with the latest Brazilian soap operas, and, more recently, schools so that the children can adapt once the family returns to Brazil.

Japan facilitated this boom of nikkeijin migration. In need of factory workers during the Bubble Economy of the 1980s and faced with a growing number of illegal workers from the Middle East and Asia, in 1990 the Japanese Government revised the Immigration Law of 1951. At the same time that it established criminal penalties for the recruitment of those foreign workers, it created a new 'long-term' visa exclusively for descendants. The reasons given were deeply related to race: Japanese descendants would maintain racial, ethnic and social homogeneity while helping Japan to overcome the crisis of lack of factory workers in an increasingly middle-class society.

The expectation that Japanese-Brazilians would behave and think like Japanese was, of course, flawed. Both sides - Japanese and Japanese-Brazilians - underwent cultural shock when they came in contact. The paradox of being considered Japanese (and called so) in Brazil, and becoming aware of the profound differences between themselves and the Japanese in Japan, came to many as a loss and, subsequently, a transformation in their identity. But the suffering also comes from a change in status on two fronts: from being regarded positively in Brazil due to their Japanese ethnicity, they became persona non grata in Japan due to their Brazilian origin; and from middle-class status holding white collar jobs in Brazil, they became part of the disenfranchised class holding blue collar jobs in Japan. Feeling unwelcomed, not speaking the language and thus not fitting into the society, Brazilian nikkeijin adopt an overtly Brazilian identity in Japan. As Tsuda puts it, they 'perform a Brazilian counteridentity'7 by wearing colourful Brazilian clothes, dancing in samba parades (many for the first time in their lives), and speaking Portuguese in public. However, according to Tsuda, this is only contributes to strengthening the stigma: the Japanese feel disappointed at the Brazilian nikkeijin's loss of Japanese culture. ${ }^{8}$

${ }^{7}$ Tsuda, Strangers in the Homeland, p. 263.

${ }^{8}$ Ibid. 


\section{Japan-Brazil Connections: Chanoyu as a Marker of Japanese Identity}

I have never really had to grapple with such stigma. My identity as a scholar and someone who did not have Japanese ancestors made the Japanese not expect any previous knowledge of their culture from me. Everything I already knew or learned in Japan was praised as a great achievement. Moreover, in Japan I have always lived in Kyoto, far from Hamamatsu City, where Brazilian-Japanese dwelled because of the area's large number of auto-parts factories. Communicating in Japanese and English also gave me a status the nikkeijin did not have. Finally, studying chado at the Urasenke headquarters and later researching the Sōtō Zenshū School of Buddhism meant that I was associated with 'high culture' and not with 'poor' migrants.

The first time I lived in Japan (1991-92), I dwelt at the Urasenke School and was thus intensively immersed in Japanese traditional culture. Dressed in kimono all day, sleeping on a futon and tatami mats, having baths at the sentō, I applied myself to learning all about seasonal feelings, flowers, pottery, fabric, Zen scrolls, lacquer, bamboo, wooden and paper utensils, the names of several generations of families that supplied utensils to Urasenke, as well as preparing and drinking tea. Having had that inkling of this way of learning while studying ikebana almost a decade earlier, I enjoyed this intense embodied experience. However, it was still not easy just to copy the teacher and be frowned upon when I asked questions.

After this intensive year in Japan, my MPhil thesis benefited considerably from a deeper understanding of the ways in which culture travels and is translated. It was crucial to first comprehend how chado developed in Japan and what role it played in politics in the $16^{\text {th }}$ and $17^{\text {th }}$ centuries, when it was constructed as the quintessential traditional Japanese art. Only then was I able to fathom its significance in the construction of the identity of Japanese migrants in Brazil, which was the topic of my thesis. By uniting the teachings of a tradition, culture and appropriate behaviour, chanoyu became an ideal art for the transmission of values of Japanese culture, and is perceived as a true symbol of what it is to be Japanese. ${ }^{9}$ Indeed, at Urasenke I realised that, whenever foreign heads of state visit Japan, it is not to the industrial Japan that the visitor is taken, but to a session of chanoyu promoted for him or her to experience a 'taste of Japan. ${ }^{10}$ Although chanoyu is not part of Japanese daily life, it is also to demonstrations of this art that the ordinary Japanese takes his or her foreign guests. The contact of the majority of the Japanese with the world of tea ceremony, if it happens, takes place in school, where there is usually a tea club. However, the vast majority do not keep an interest in chanoyu when they become adults; consequently they know very little about it. This lack of knowledge does not present itself as a problem, quite the opposite: it helps in the mystification of what the 'Japanese spirit' is thought to be - something distant, which hovers in the horizon,

\footnotetext{
${ }^{9}$ Mori, Chadō in Japan and Hawaii, passim.

${ }^{10}$ See Urasenke Newsletter, 1975-2006
} 
as a mirror reflecting what the Japanese should or would like to be. The main point is that chanoyu, as an institution, is maintained so that the Japanese are able to use it to set the boundaries of their culture in face of 'the other'. Indeed, anthropologist Barbara Mori notes, 'When the Japanese were asked to choose which aspects of Japanese culture to introduce to foreign countries, chado and flower arrangement ranked second only to shrines, temples and castles.'11

Given this level of prestige and status as a vehicle for the transmission of traditional culture, it is easy to see why immigrants would be eager to learn it once they were given the opportunity. Had I not uncovered the ways in which chanoyu is constructed in Japan, I would not have been able to realise its importance as a marker of identity for first-generation migrants. By the same token, I would not have understood why second-generation migrants were not too keen to learn it since they had already started the process of becoming Brazilians. However, since the 1980s, when Japan became a leading economic power, nisei and sansei Brazilians have begun to take a renewed interest in their ethnic origins, to see themselves as Japanese and to study traditional arts, including chanoyu. In this period, the prestige of Japan in the world, and the recognition from mainstream society of its culture as a symbol of refinement, also attracted a new group of students to chanoyu: non-Japanese Brazilians. For them, chanoyu offered an introduction to Japanese culture and Zen Buddhism. Chanoyu, a 'Zen art', now attracts those Brazilians following the international trend of interest in Zen and Buddhism in general. ${ }^{12}$

My $\mathrm{PhD}$ research and recently published book on Zen in Brazil ${ }^{13}$ followed the same reasoning as the one on chanoyu. In order to understand how Zen and the Sōtō Zenshū School adapted its rituals and practices to Brazil, I learned about it in Japan before it was culturally translated. Establishing historical and transnational connections was central to an understanding of how and why Buddhism in general, and Zen in particular, has found a place in the Brazilian religious field and urban culture. It was thus clear from the start that if I wanted to encompass the transnational flows of Zen into Brazil, my field should be a multi-sited one.

\section{Multi-Sited Ethnography: Connecting Sites in a Globalised World}

In the past decade or so, several anthropologists have been reflecting on the implications of globalisation and transnational communities for the ethnographic method. ${ }^{14}$ From this perspective, traditional conceptions of the anthropological field as the territorially

\footnotetext{
${ }^{11}$ Mori, op. cit., p. 218.

${ }^{12}$ For more on chanoyu in Brazil, see Rocha, 'Tea Ceremony in Japan' and 'Identity and Tea Ceremony in Brazil.'

${ }^{13}$ Rocha, 'Zen in Brazil'.

${ }^{14}$ Clifford, Routes; Jean and John Comaroff, Ethnography and the Historical Imagination; Comaroff and Comaroff, 'Introduction'; Mary Des Chene, 'Locating the Past', pp. 66-85; Gupta and Ferguson, 'Discipline and Practice'; George Marcus, Ethnography through Thick and Thin; George Marcus, 'Beyond Malinowski and After Writing Culture', pp. 191-99; George Marcus and Michael M. Fisher, Anthropology as Cultural Critique.
} 
fixed, stable, localised and bounded community have become inadequate. For instance, George Marcus has called for 'multi-sited ethnography' as a way of 'examining the circulation of cultural meanings, objects, and identities in diffuse time-space. ${ }^{15}$ For him, 'multi-sited research is designed around chains, paths, threads, conjunctions, juxtapositions of locations in which the ethnographer establishes some form of literal, physical presence, with an explicit, posited logic of association or connection among sites that in fact defines the argument of the ethnography. ${ }^{16}$ Even within single sites, Marcus sees the awareness of a much larger world-system in the subjects' consciousness and actions as crucial. In the same vein, James Clifford has observed that in such an increasingly interconnected world, 'the ethnographer is no longer a (worldly) traveller visiting (local) natives, ${ }^{17}$ rather both are travellers as well as dwellers. According to Clifford, if one is to understand 'local/global historical encounters, [...] dominations and resistances, one needs to focus on hybrid, cosmopolitan experiences as much as rooted, native ones. ${ }^{18}$

To this end, my book addresses both experiences. Whereas I focus on the 'local/global historical encounters' and the cosmopolitan experiences of my interviewees (as many of them were in fact cosmopolitans who travelled, and were aware of developments of Zen in metropolitan centres), I also focused on how they engaged in their Zen practices in Brazil. Accordingly, I conceived the book as a multi-sited research in order to track the flows of Zen from Japan, Europe and the US into Brazil, and as they made their way back into these countries as well as to Latin America.

I therefore deployed Appadurai's global 'scapes' to illuminate the creation of an imaginary of Zen in particular, and of Buddhism in general, in Brazil. ${ }^{19}$ Among these scapes are: flows of people (Japanese immigrants into Brazil, Sōtōshū kaikyōshi/missionaries travelling among overseas outposts, and non-Japanese Brazilians travelling to the US, Europe and Japan to learn about and practise Zen), flows of technology (by looking at who writes and what is discussed on Brazilian Buddhist email lists, and how these compare with the international Buddhist lists), flows of media (looking at how media stories produced overseas influenced media production in the country, and how they in turn influence Brazilian followers), and flows of ideas (contained in movies, in foreign books translated into Portuguese, and in Brazilian books). Importantly, such flows were never univocal, and they have been significant in the creation of a conflicting reception of Zen among Japanese, Japanese-Brazilians and non-Japanese Brazilians in the country.

In very broad terms, from the start there have been two conflicting definitions of Zen Buddhism, both sides claiming to practise 'authentic' and 'true' Zen Buddhism. While some kaikyōshi and the Japanese community have asserted that Zen is comprised of devotional practices, worship of ancestors and funeral rituals; other kaikyōshi and

\footnotetext{
${ }^{15}$ Marcus, Ethnography through Thick and Thin, pp. 79-104.

${ }^{16}$ Ibid., p. 79.

${ }^{17}$ Clifford, Routes, p. 2.

${ }^{18}$ Ibid., p. 24.

${ }^{19}$ Appadurai, Modernity at Large.
} 
(mostly) non-Japanese Brazilian practitioners have claimed that Zen relies mainly on zazen in order to experience enlightenment. The same state of affairs has been observed in many Western countries where Buddhism emerged and developed as a result both of immigration and religious conversion ${ }^{20}$. To be sure, this division is a superficial picture of Zen in Brazil. A more nuanced approach reveals a blurred area where JapaneseBrazilians, who have been Catholic for many generations, have become interested in Zen through zazen, while some non-Japanese Brazilians have developed a devotional attitude towards Zen.

Furthermore, the dynamic of these flows of people, technology, media and ideas is what we may call 'rhizomatic.' ${ }^{21}$ Like in a rhizome, Brazil is one of the nodes, albeit less influential, in the web of the global flows of Zen. Indeed, Zen in Brazil was never isolated from the trends occurring overseas. The arrival of Japanese immigrants and the rotation of Sōtōshū missionaries amongst the diverse temples outside Japan, Brazilian intellectuals travelling to metropolitan centres and translating books on Zen, the media, and, more recently, the internet, have meant that Brazil has received inflows, but has also produced counterflows of Zen.

\section{Conclusion: Being a Brazilian-Australian Scholar}

While writing my book, I once again had to grapple with cultural translation. For my Masters dissertation I had addressed translation between two cultures (Japan and Brazil) and two languages (Japanese and Portuguese). This time, writing the book in Australia meant that I had to work across three cultures and three languages. When I was awarded a Japan Foundation Doctoral Fellowship to research the Sōtō Zenshū School in 2000, I had been living in Australia for one year. This fact had an impact in my research that I had not predicted. Not only did interviews have to be translated from Japanese and Portuguese into English, but writing in Australia meant that the book had to answer to the many questions Australians asked me about Brazil and the particularities of Zen and the Japanese migrants in Brazil.

Moreover, the historical connections between Australia and Japan were utterly different from those between Brazil and Japan, as I mentioned before. While I lived in Japan and was affiliated with the National Museum of Ethnology of Osaka in 2000, things had also changed for me. I was no longer regarded as a Brazilian scholar, but as a Brazilian-Australian one. Interestingly, for the Japanese it seemed that the war had not really left a mark in the same sense. Mostly, people smiled and told me of past or wished-for holidays in Australia. 'Koaras' and kangaroos were always mentioned affectionately. Given that Australia was a Mecca for Japanese tourism throughout the 1980s and 1990s,

\footnotetext{
${ }^{20}$ See, for example, Baumann, 'Creating a European Path to Nirvana' and 'Global Buddhism; Fields, 'Divided Dharma'; Nattier, 'Visible and Invisible' and 'Who is a Buddhist?'; Numrich, Old Wisdom in the New World; Prebish 'Two Buddhisms Reconsidered'.

${ }^{21}$ The term was first used by Gilles Deleuze and Felix Guattari in A Thousand Plateaus.
} 
it was obvious that it would steer memories of sun-drenched beaches and pleasure. Its proximity to Japan also guaranteed that many knew where Sydney was as opposed to São Paulo, my birth place. In this context, it was definitely easier to relate to my interviewees as a scholar from an Australian university.

It is noteworthy that, during my research, I realised that the way in which Buddhism is experienced in Brazil is not peculiar to that country. As is the pattern amongst Brazilians, there are increasing numbers of Australians and people in other Western countries who are shying away from their religion of birth and instead adopting 'spiritualities of choice'. Buddhism is now the fastest growing religion in Australia, having grown 80 percent between the 1996 and 2001 censuses. This surge is not only due to migration and refugees from Laos, Cambodia and Vietnam, but also to large numbers of Australians converting to Buddhism. Studies done in Australia show that, as in Brazil, Buddhism is attractive because it provides a powerful antidote to the stress and violence of today's world. ${ }^{22}$

What I find interesting is how Westerners imagine Buddhism and Buddhist monks/nuns. How they associate them with peace, love, happiness, and compassion. When I first lived in Japan in the early 1990s, many Japanese friends told me they thought that Buddhist monks were strongly related to money. In addition, Buddhism in Japan is not connected with happiness at all, but is associated with funerary rituals. Shintō is associated with life rituals, as marriages and births are celebrated in Shintō shrines. What is more, many Japanese related all these qualities (peace, love, happiness, and compassion) with Catholicism. By contrast, in Brazil, the largest Catholic country in the world, many think that Catholic priests and the Church are heavily associated money. In this light, the process of cultural translation is fascinating. What happens when Buddhism arrives in the largest Catholic country in the world? How it is imagined? What attracts Brazilians to Buddhism? These are some of the questions my book answers.

Looking back, I can see that I have always been interested in how the imagination is historically constructed and, in turn, shapes the way people behave. Starting from the prestigious role chanoyu acquired in Japan, to how it was constructed by the Japanese migrants in Brazil, to the images and ideas associated with Zen Buddhism and Japan (what we could call Orientalism in Brazil), my research work has always been centred on how ideas move around certain locales, and how they are translated and recreated in the new setting as hybrids which are not solely part of either the culture of the sending or the host countries. They are original creations. Nowadays, I am still connected with both of my main research topics: I study chado in Sydney, I am the editor (with Rebecca Corbett in this volume) of Tea Leaves, the newsletter of the Urasenke Sydney Association, and I sit zazen. Now that I live permanently in Australia, I am soon to start new research focusing on Japanese-Australian religious connections. I would like to explore the ways in

${ }^{22}$ For more on Buddhism in Australia, see Spuler, Developments in Australian Buddhism. 


\section{which some Australians have adhered to Shinnyo-en and how this new Japanese Buddhist religious movement has been expanding in this country.}

\section{References}

Appadurai, A., Modernity at Large (Minneapolis: University of Minnesota Press, 1996).

Baumann, M., 'Creating a European Path to Nirvâna: Historical and Contemporary Developments of Buddhism in Europe', Journal of Contemporary Religion 10:1, 1995, pp. 55-70.

__, 'Global Buddhism: Developmental Periods, Regional Histories, and a New Analytical Perspective.' Journal of Global Buddhism 2, 2001, pp. 1-44.

Befu, H., 'Globalization Theory from the Bottom Up', Japanese Studies 23:1 2003, pp. 3-22.

Clifford, J., Routes: Travel and Translation in the Late Twentieth Century (Cambridge: Harvard University Press, 1997).

Comaroff, J. and Comaroff, J., Ethnography and the Historical Imagination (Boulder, San Francisco, Oxford: Westview Press, 1992).

—_, 'Introduction', in Comaroff, J. and Comaroff, J. (eds), Modernity and Its Malcontents: Ritual and Power in Postcolonial Africa (Chicago \& London: The University of Chicago Press, 1993).

Deleuze, G. and Guattari, F., A Thousand Plateaus: Capitalism and Schizophrenia (Minneapolis: University of Minnesota Press, 1987).

Des Chene, M., 'Locating the Past', in Gupta, A. and Ferguson, J. (eds), Anthropological Locations (Berkeley, Los Angeles and London: University of California Press, 1997), pp. 66-85.

Fields, R., 'Divided Dharma: White Buddhists, Ethnic Buddhists, and Racism', in Prebish, C. and Tanaka, K. (eds), The Faces of Buddhism in America (Berkeley: University of California Press, 1998), pp. 196-206.

Gupta, A. and Ferguson, J., 'Discipline and Practice: "the Field” as the Site, Method, and Location in Anthropology' in Gupta, A. and Ferguson, J. (eds), Anthropological Locations (Berkeley, Los Angeles and London: University of California Press, 1997), pp. 1-46.

George M., Ethnography through Thick and Thin (Princeton: Princeton University Press, 1998).

—_, 'Beyond Malinowski and After Writing Culture', The Australian Journal of Anthropology 13:2, 2002, pp. 191-99.

George M. and Fisher M., Anthropology as Cultural Critique (Chicago: University of Chicago Press, 1986).

Iwabuchi, K., Recentering Globalization (Durham: Duke University Press, 2002).

Lesser, J., Negotiating National Identity: Immigrants, Minorities, and the Struggle for Ethnicity in Brazil (Durham: Duke University Press, 1999).

Lone, S., Japanese Community in Brazil, 1908-1940: Between Samurai and Carnival (Houndmills: Palgrave, 2001). 
Mori, B., 'Chadō in Japan and Hawaii: A Symbolic Interactionist Analysis of Intra- and Cross Cultural Transmission, Adaptation and Change.' (Ph.D. dissertation, University of Hawaii, 1988).

Nattier, J., 'Visible and Invisible: Jan Nattier on the Politics of Representation in Buddhist America.' Tricycle: The Buddhist Review 17: V, Fall 1995, pp.42-49.

_- 'Who Is a Buddhist? Charting the Landscape of Buddhist America', in Prebish, C. and Tanaka, K. (eds), The Faces of Buddhism in America (Berkeley: University of California Press, 1998), pp. 183-95.

Numrich, P., Old Wisdom in the New World: Americanization of Two Immigrant Theravada Buddhist Temples (Knoxville: The University of Tennessee Press, 1996).

Prebish, C., 'Two Buddhisms Reconsidered.' Buddhist Studies Review 10: 2, 1993, pp. 187-206.

Rocha, C., 'Identity and Tea Ceremony in Brazil'. Japanese Studies 19: 3, 1999, pp. 287-95.

_- 'Tea Ceremony in Japan and Its Appropriation in Brazil: A Metaphor of the Japanese Spirit', in Helsloot, J. et al (eds), Roots and Rituals: The Construction of Ethnic Identities (Amsterdam: Het Spinhuis, 2000), pp. 527-37.

— Zen in Brazil: The Quest for Cosmopolitan Modernity (Honolulu: University of Hawaii Press, 2006). Spuler, Michelle, Developments in Australian Buddhism: Facets of the Diamond (NY and London: Routledge Curzon, 2003).

Takenaka, A., 'Japanese Peruvians and their Ethnic Encounters', in Rustomji-Kerns, R. et al. (eds), Encounters: People of Asian Descent in the Americas (Lanham, Boulder, NY, Oxford: Rowman \& Littlefield, 1999), pp. 113-118.

Takeyuki T., 'From Ethnic Affinity to Alienation', Diaspora 10:1, 2001, pp. 53-91.

—, Strangers in the Homeland: Japanese Brazilian Return Migration in Transnational Perspective (New York: Columbia University Press, 2003).

Urasenke Newsletter, 1975-2006, published by the Urasenke School of Tea in Kyoto. 